\title{
A review of African horse sickness and its implications for Ireland
}

Geoffrey M Thompson ${ }^{1,2^{*}}$, Stephen Jess ${ }^{2}$ and Archie K Murchie ${ }^{2}$

\begin{abstract}
African horse sickness is an economically highly important non-contagious but infectious Orbivirus disease that is transmitted by various species of Culicoides midges. The equids most severely affected by the virus are horses, ponies, and European donkeys; mules are somewhat less susceptible, and African donkeys and zebra are refractory to the devastating consequences of infection. In recent years, Bluetongue virus, an Orbivirus similar to African horse sickness, which also utilises Culicoides spp. as its vector, has drastically increased its range into previously unaffected regions in northern Europe, utilising indigenous vector species, and causing widespread economic damage to the agricultural sector. Considering these events, the current review outlines the history of African horse sickness, including information concerning virus structure, transmission, viraemia, overwintering ability, and the potential implications that an outbreak would have for Ireland. While the current risk for the introduction of African horse sickness to Ireland is considered at worst 'very low', it is important to note that prior to the 2006 outbreak of Bluetongue in northern Europe, both diseases were considered to be of equal risk to the United Kingdom ('medium-risk'). It is therefore likely that any outbreak of this disease would have serious socio-economic consequences for Ireland due to the high density of vulnerable equids and the prevalence of Culicoides species, potentially capable of vectoring the virus.
\end{abstract}

Keywords: African horse sickness, Culicoides spp., Epizootic disease, Ireland

\section{Introduction}

African horse sickness (AHS) is a disease caused by the African horse sickness virus (AHSV). The disease affects horses, ponies, and European donkeys most severely; mules are somewhat less affected, and African donkeys and zebra are refractory to the devastating consequences of infection [1-4]. The virus is a non-contagious, vectorborne Orbivirus that is transmitted primarily by female Culicoides midges during a blood meal, which they require for reproduction [4]. In addition to equids, camels, goats, and buffalo can become infected [5]. Additionally, some carnivores such as dogs, can become infected via ingestion of contaminated meat. However, there have been no documented cases of transmission of AHSV in carnivores in the wild, and it is considered that they are a 'dead-end' host, rather than a reservoir of infection $[6,7]$. Owing to the potential of this virus to cause

\footnotetext{
* Correspondence: Geoffrey.Thompson@afbini.gov.uk

${ }^{1}$ School of Biological Sciences, Queen's University of Belfast, Belfast BT7 1NN, Northern Ireland

${ }^{2}$ Agri-Food and Biosciences Institute, Newforge Lane, Belfast BT9 5PX,

Northern Ireland
}

widespread death and debilitating disease in naïve equid populations, it is listed as a notifiable equine disease by the World Organisation for Animal Health (OIE), which makes outbreaks of the disease compulsorily notifiable to the OIE. Such occurrences can result in serious consequences for international trade of animals and animal products for the affected country [8]. It is currently predicted, that a widespread outbreak of this disease would have a devastating effect on the horse industry of any country affected [9].

\section{History}

The first recorded reference of AHS occurred in 1327 in Yemen [10], but it is most likely that the virus originated on the African continent where it could have been transmitted in the natural zebra population [2]. The disease was first recognised around 60 years after the initial introduction of horses to Africa in 1657, and the first major outbreak occurred in 1719. This outbreak resulted in the deaths of approximately 1, 700 animals [11]. Subsequently, there has been at least an additional 10 major

\section{Biomed Central}


(and several lesser) outbreaks of AHS on the African continent [2]. These outbreaks typically coincide with warm-phase El niňo southern oscillation (ENSO) events [12] and they have had devastating results for the African horse population, most notably, the 1854-1855 outbreak in South Africa, which resulted in the deaths of around 70, 000 animals [13,14]. Throughout the last century, there has been a steady decline in the number of cases of AHS in South Africa, which correlated with a decline in the number of wild zebra due to hunting. Currently, AHS is not considered to be endemic in the greater part of South Africa, with the exception of the North-eastern Lowveld of Mpumalanga Province where seroconversion of AHSV occurs in zebra in every month of the year and virtually all adult animals have specific antibodies to all nine serotypes of the virus. Typically, the disease first appears in the North-eastern part of the country in December/January and subsequently spreads southwards, occasionally reaching as far as the Western Cape Province [14]. However, it has been reported that restocking of zebra is occurring in many areas of South Africa and that at some point, conditions for the re-establishment for AHS in other regions of the country may occur [2]. These conditions appear to have been reached in recent years, with a number of outbreaks of AHSV serotype 1 (AHSV-1) recorded in the Western Cape Province, with a horse case fatality rate of more than $90 \%$ [15].

While AHS is considered to be primarily an African disease, there have been a number of epizootic events that have occurred outside this region. The most severe of which occurred in Asia between 1959-1961, when AHSV serotype 9 (AHSV-9) spread throughout Afghanistan, Cyprus, India, Iraq, Jordan, Lebanon, Pakistan, Saudi Arabia, and Syria resulting in the deaths of around 300, 000 equids [2,3,16-18]. This outbreak was followed by another epizootic of AHSV-9 in 1965 which spread throughout Morocco, Algeria, Tunisia and Spain. It is believed that the movement of nomads and their donkeys across the Sahara was responsible the appearance of AHSV-9 in northern Africa [2].

Following these outbreaks, AHS was confined to subSaharan Africa for around 20 years until July 1987, when AHSV serotype 4 (AHSV-4) was reported in central Spain [19]. This serotype had never before been recorded outside of Africa [20], and it is believed that the outbreak was caused by the importation of a number of sub-clinically infected zebra from Namibia to a safari park at Aldea del Fresno [19]. This site subsequently became the foci for the first 27 cases of AHS in Europe [21]. Over the following months, the outbreaks continued to spread within central Spain until October, when temperatures became too low for the virus transmission cycle to continue. It was initially hoped that this break in the transmission cycle would remove the infection from the region, but this was not the case, and AHSV successfully overwintered in the European climate. Subsequently, new outbreaks occurred in Spain (1988-1990), Portugal (1989) and Morocco (1989-1991) [20] indicating that the virus had persisted in the area for at least five years and successfully overwintered on four occasions. In total, the outbreak in Spain resulted in the deaths of over 400 equids, and a further 900 were destroyed in attempts to control the virus spread. It was not until 1990, when a monovalent vaccine was administered to more than 350,000 susceptible animals, that the outbreak was controlled [20,22]. Portugal reported a total of 206 cases, but here the infection was removed quickly following a mass vaccination policy, eradication on infected farms, and strict animal movement controls. The total cost of the 13-week incursion into Portugal was estimated at around US \$ 2 million [23]. While this figure may seem high compared to the total number of deaths (US \$ 9, 493/mortality), when compared to the Portuguese equine population as a whole, the total cost of this campaign appears relatively small (170, 000 animals, US \$ 11.50/animal). This campaign must therefore be seen as successful, as it drastically reduced the potential damage to the Portuguese equine industry [23].

\section{The African horse sickness virus}

There are currently nine recognised serotypes of AHSV worldwide, the last of which was identified in 1960 [24]. The AHSV is a double-stranded RNA virus from the genus Orbivirus (family Reoviridae), and as such, it is morphologically similar to other Orbiviruses such as Bluetongue virus (BTV), Epizootic haemorrhagic disease virus (EHDV), and Equine encephalosis virus (EEV) $[1,7,25,26]$. The virion, which is approximately $70 \mathrm{~nm}$ in diameter, is made up of a two-layered icosahedral capsid [13]. This capsid encloses the genome which comprises ten segments of linear double stranded RNA [26,27]. The outer shell of the capsid comprises two structural proteins (VP2 and VP5), which are involved in virus attachment and cell entry. These are the most variable proteins and as such are used to determine the virus serotype (usually VP2) [4,28-31].

\section{Pathogenesis}

Despite the distinct differences in the clinical severity of AHS infection in different equids, the typical pattern of pathogenesis is similar. Following exposure through the bite of an infected vector, the virus initially replicates in an adjacent lymph node before disseminating throughout the entire body via the circulatory system. This is the primary viraemia which leads to infection of the lungs and lymphoid tissues. The virus then undergoes a further replication cycle in these target organs which in turn gives rise to a secondary viraemia. The virus has a predilection for the vascular endothelial cells throughout the body, causing extensive damage including effusions into 
body cavities and tissues, and widespread haemorrhages [13]. The duration of this process from initial infection to secondary viraemia can vary between 2-21 days, although it usually takes less than nine [32]. In horses, the period of viraemia usually lasts between 4-8 days, whereas in donkeys, it may persist for up to four weeks. In zebra, this period may be extended to approximately 40 days post-infection $[4,13,18,33]$. In common with BTV, AHSV is often associated with red blood cells of the infected animal throughout both primary and secondary viraemia. In ruminants infected with BTV, this often leads to an extended period of viraemia, although this does not appear to be the case with AHS [2].

\section{Clinical signs}

AHSV displays itself in the form of four diseases: cardiac form, pulmonary form, mixed form, and horse sickness fever [34].

The cardiac form of the disease is usually characterised by the development of a fever, oedema of the head, neck, chest, supraorbital fossae, petechial haemorrhages in the eyes (Figure 1), ecchymotic haemorrhages on the tongue, and colic. In these cases, mortality of infected animals may exceed $50 \%$ [13].

The pulmonary form of the disease is the most serious. It is typically associated with a rapid onset of symptoms which include the development of a fever, depression, severe respiratory distress (Figure 2), severe dyspnoea, coughing, and sweating. Typically, the mortality rates of this form of the disease exceed 95\% [13].

The mixed form is often the most common form of the disease and as the name suggests, it is a combination of the cardiac and the pulmonary form. Typically, the mortality rate may exceed $70 \%$, and death can often occur within three to six days [13].

Horse sickness fever is the mildest form of the disease, during which, the animal will develop a moderate fever and some oedema of the supraorbital fossae (Figure 3).

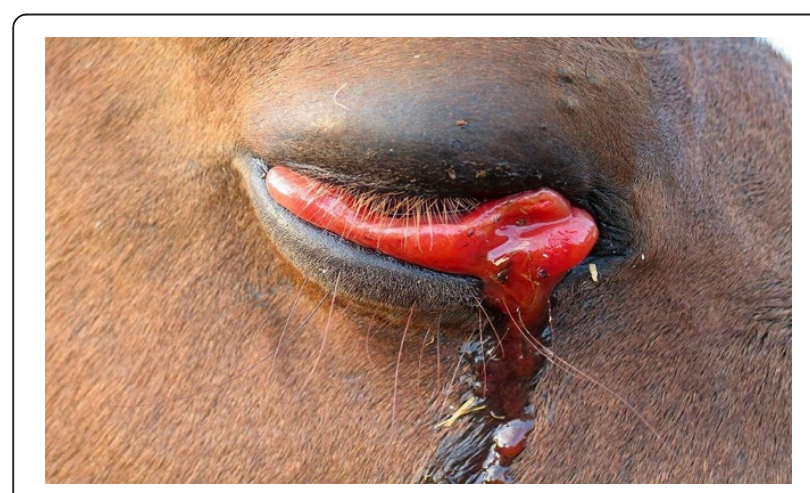

Figure 1 Horse suffering from petechial haemorrhage. Picture courtesy of the Institute for Animal Health, Pirbright.

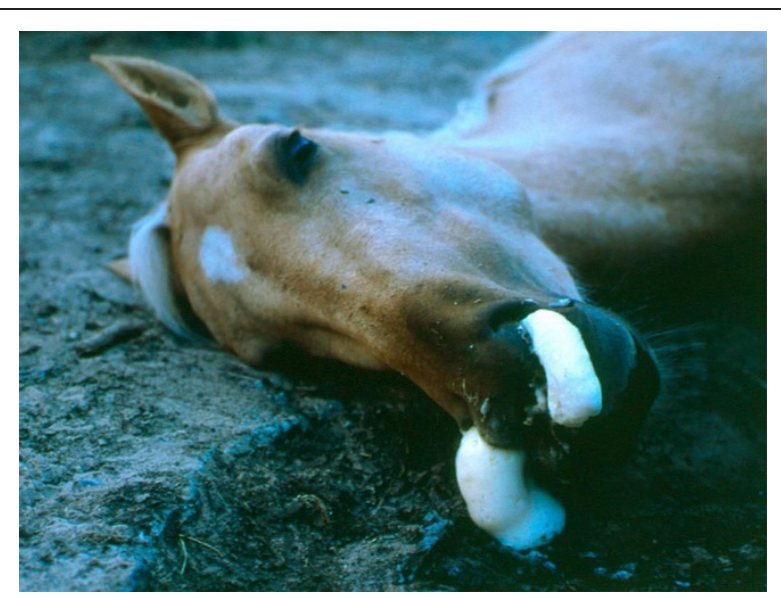

Figure $\mathbf{2}$ Horse suffering from severe respiratory distress. Picture courtesy of the Institute for Animal Health, Pirbright.

There is no mortality associated with this form of the disease [13].

\section{The African horse sickness vector}

The principal vector of AHSV is the female midge of the genus Culicoides (Diptera: Ceratopogonidae). These insects are important vectors of a number of viral diseases worldwide including: Akabane, Bovine ephemeral fever, Bluetongue, Epizootic haemorrhagic disease, Equine encephalosis, Oropouche, and The Palyams [1,35]. It was first discovered that adult females from the genus Culicoides were the principal vector for AHSV in 1944 [36]. Today there are approximately 1, 340 recognised species of Culicoides worldwide, of which $96 \%$ are obligate bloodsuckers [37]. Typically, Culicoides spp. measure between 1-3 mm, making them amongst the smallest haematophagous flies in the world, and they are currently found on all

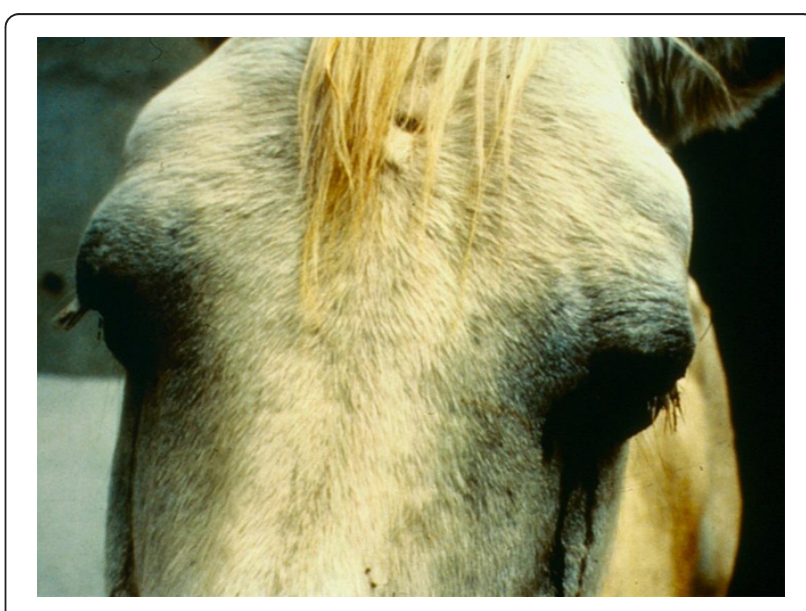

Figure 3 Horse exhibiting oedema of the supraorbital fossae. Picture courtesy of the Institute for Animal Health, Pirbright. 
continents (except Antarctica) from sea level up to around 4, $200 \mathrm{~m}$ (in Tibet) [38].

The principal vector of AHSV worldwide is Culicoides imicola [39], which is a common species distributed throughout Africa, much of Southeast Asia, and southern Europe [2]. It has been reported that over 1 million individuals may be captured in a single light trap per night [40]. It was previously considered that C. imicola was the only species of Culicoides capable of vectoring AHSV, but other species have been identified as potential vectors. A laboratory study in 1975 found that the American BTV vector, Culicoides variipennis (sonorensis), also has the ability to transmit AHSV [41]. Additionally, AHSV has also been isolated from the northern European BTV vectors, Culicoides obsoletus and Culicoides pulicaris, during the AHSV-4 outbreak in Spain $[42,43]$. However, it is important to note that the presence of virus does not necessarily indicate that these midges are capable of virus transmission. More recently, Culicoides bolitinos has been implicated as a vector in Africa, particularly at higher altitudes where C. imicola is rare $[44,45]$.

While Culicoides spp. are widely considered to be the principal vector for the transmission of AHSV, a number of other species have been implicated in its transmission. Laboratory experiments have shown that some species of mosquito, most notably Aedes aegypti, Anopheles stephensi, and Culex pipiens, are capable of AHSV infection and transmission [4,41,46-49]. Although, the virus only underwent multiplication in a limited number of mosquitoes and the maximum virus titre was not appreciably higher than the amounts ingested, an eclipse phase occurred subsequent to infection and virus was recovered for at least five weeks [41]. Additionally, AHSV has also been isolated in the field from samples of camel ticks, Hyalomma dromadarii, in Egypt [50]. However, the prevailing scientific opinion suggests that the role of these species in the transmission of AHSV is likely to be insignificant [4].

\section{Overwintering}

Throughout the majority of the geographic range of AHSV, the climate is suitable for vector activity and viral replication to occur throughout the year [4]. For example, in northeast South Africa it has been found that seroconversion of AHSV occurs in every month of the year in zebra [2]. However, in some regions, conditions are not suitable for year round vector activity or viral replication, and a break in the transmission cycle occurs e.g. Spain (1987-1990). This poses the question as to where and how does the virus survive over the winter period? Similar to BTV, there are a number of possible mechanisms by which AHSV could be overwintering (Figure 4): 1) in the vector population, 2) in the host population, 3) via an alternative transmission cycle involving an unknown vector or host [4].

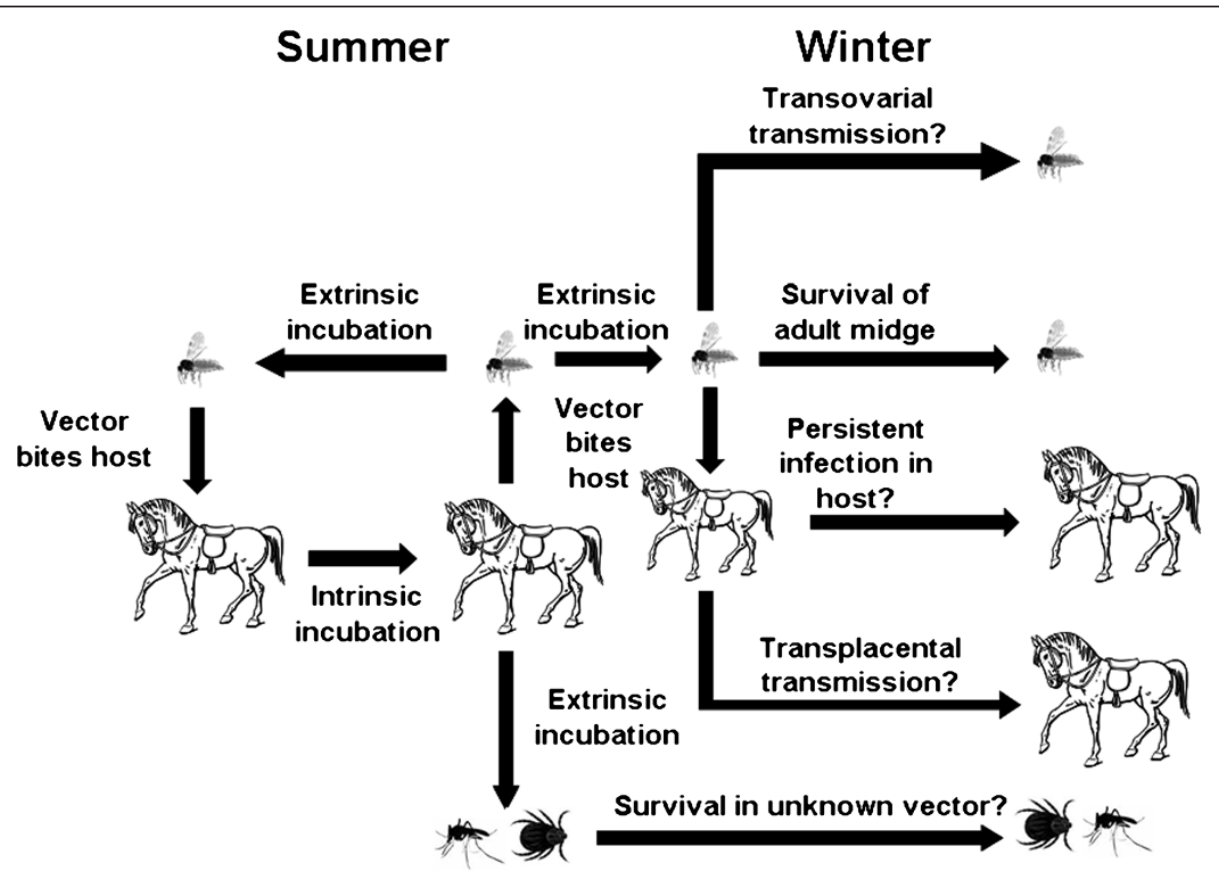

Figure 4 The normal transmission cycle of African horse sickness virus in summer (Left) and possible overwintering mechanisms (Right). Image created using Microsoft Clip Art with permission from Microsoft PowerPoint (2007). 


\section{1) Survival in the vector}

There are two possible means by which AHSV may survive the winter in the adult vector population. The first is via transovarial transmission (vertical transmission of AHSV from adult females to their eggs). While there is evidence that vertical transmission of arboviruses occurs in mosquitoes and sandflies $[35,51,52]$, to date, no evidence of live AHSV has been recovered in any larval Culicoides spp.. Hitherto, only fragments of BTV RNA have been found in larvae and further research is required in order to fully understand if this route of transmission exists [53].

A second, better understood method, involves virus retention in adult Culicoides which survive the winter drop in temperatures. Culicoides imicola activity has been recorded at temperatures as low as $12^{\circ} \mathrm{C}[54,55]$. At these temperatures, the life span of some Culicoides spp. can be extend up to 90 days $[55,56]$. While viral replication ceases at temperatures below $15^{\circ} \mathrm{C}$, once temperatures raise above this point, viral replication may resume in a number of individuals [55]. Under these circumstances, AHSV may overwinter within the adult vector population, provided some infected individuals survive through the winter period. This mechanism was implicated in the successful overwintering of AHSV in Spain, Portugal, and Morocco [39,57].

\section{2) Survival in the vertebrate host}

While the survival of AHSV in adult Culicoides spp. remains a better understood mechanism for virus overwintering, there are a number of possible means by which the virus may overwinter within the vertebrate host. Whilst persistent or chronic infection in horses is considered unlikely as the period of viraemia is short (4-8 days) and the mortality rates are high (often $>95 \%$ ) [13], donkeys may remain viraemic for up to four weeks, and the viraemic period of zebra can extend up to around 40 days $[4,13,18,33]$. This creates the possibility that chronically infected animals may represent a possible mechanism for overwintering of AHSV, although there is no current field evidence to support this hypothesis [4].

Another recently discovered overwintering mechanism for Orbiviruses is the possibility of vertical transmission within the host. To date, there has been no evidence to suggest that this route occurs for AHSV, but recent studies involving BTV-8 in northern Europe have demonstrated that this mechanism occurs within cattle [58], and it may be possible that it also occurs for AHSV, although further research is required to establish if this mechanism exists.

\section{3) Survival in an unknown vector or host}

The final mechanism by which AHSV may be overwintering, is in a vector species other than Culicoides such as ticks, which can live for several years, easily bridging the winter gap [59]. It has long been known that AHSV has been isolated in the field from samples of camel ticks, Hyalomma dromadarii [50], and a number of experiments have shown that some species of mosquito are capable of AHSV infection and transmission [4,46-49]. However, the prevailing scientific opinion suggests that the role of these species in the overwintering of AHSV is likely to be negligible [4], and further research is required to evaluate what role, if any these species play.

\section{Implications for Ireland}

The Republic of Ireland (R.O.I.) has a longstanding equine tradition, and it is therefore unsurprising that it has the highest density of sport horses in Europe [60]. A recent estimate valuated the industry in excess of $€ 1.1$ billion per annum [61]. The current national equid population is estimated at approximately 110, 000 animals and it is believed that 53,000 people are regularly involved in horse riding activities [60]. A conservative figure of the annual expenditure within the industry is estimated at approximately $€ 400$ million [60], while the value of various racing festivals and other meetings to the local economy was valued at $€ 260$ million [61]. Similarly, in Northern Ireland (N.I.), it is estimated that around $£ 110$ million is spent per annum on equine services and products within the economy, with a further $£$ 2 million expended outside of N.I. on thoroughbred stud fees. In total, the equid population is estimated at approximately 36,000 animals with a value of around $£$ 108 million. The sector uses approximately 30, 000 acres of land ( $>1 \%$ of total agricultural land in N.I.), and is an important employer within N.I. with the core equine industry supporting 5, 657 full-time equivalents, equating to a labour value of around $£ 54$ million. In addition, the capital value of buildings and major equipment is estimated at approximately $£ 121$ million, with the two race courses at Down Royal and Downpatrick generating approximately $£ 1.7$ million per annum in sales revenue [62].

Whilst any incursion of AHSV into Ireland is likely to be relatively short lived due to the absence of any suitable reservoir host, even an isolated case, where infection is successfully contained, could result in serious economic consequences due to long-term restrictions on trade. Furthermore, in the event of a widespread outbreak, the direct loss of horses combined with the introduction of movement restrictions, could have a potentially devastating effect on the industry. It is estimated that over half the economic impact of the sector could be lost within one to two years, with irreparable damage caused to the horse racing sector and other sporting disciplines [9].

There are three main pathways by which AHS could be introduced to Ireland: importation of infected equidae, introduction of infected vectors, and importation of 
infected biological substances/germplasm [63]. Of the 843 horses imported into R.O.I. in 2009 and 2010, only four originated from a country where AHS had been reported (South Africa) [63]. Due to the strict controls on the export of horses and their products from this region, a qualitative risk assessment predicted that the risk of introduce AHSV via this route was 'very low'[63]. The same report predicted that the risk of introduction of AHSV via wind dispersal of infected vectors was currently 'negligible' due to the fact that AHSV has not been recognised in any country neighbouring Ireland. However, previous evidence has shown that Culicoides can be transported up to $700 \mathrm{~km}$ via wind dispersal and this was the most likely transmission route for the introduction of AHSV into Cyprus (1960), Spain (1966), and the Cape Verde Islands (1943 \& 1999) [64,65]. Furthermore, this method is seen as the most likely route for the introduction of Bluetongue and more recently, Schmallenberg virus into the U.K. from mainland Europe $[66,67]$. This 'negligible' status should therefore be revised in the event of any outbreak being reported in a country of close proximity. Additionally, the report considered the risk of AHSV introduction via the accidental importation of infected Culicoides by 'hitch-hiking' on trucks transporting livestock or plants to be 'negligible' as there is no evidence in the literature to suggest that such accidental transportation has ever occurred. Finally, the report considered that the risk of AHSV importation in germplasm/biological substances was 'negligible', as hitherto there has been no recorded outbreak of AHS due to the use of infected semen, ova, or embryos [63]. Overall, the current predicted risk of AHSV to the U.K. and Ireland is considered 'negligible' to 'very low' $[63,68]$. Nonetheless, it is important to note that these reports did not consider the introduction of AHSV via the illegal importation of infected equidae and/or their products. Furthermore, the predicted risk of an incursion of AHSV or BTV into the U.K. prior to the 2006 BT outbreak was considered to be of 'Medium-risk'[69]. However, outbreaks of BTV have subsequently been reported in the U.K. in 2007 [70] and in N. I. in 2008 [58]. For these reasons, and in consideration of the recent unexplained outbreaks of BTV-8 in northern Europe [71], it is important that Ireland is suitably prepared should AHSV be imported into the island.

In response to the outbreak of BTV in northern Europe, the BTV vector surveillance programme was initiated in Ireland [72]. This programme examined the activity of Culicoides spp. for one night per week at 34 farmland trapping sites throughout the year. In total, approximately half a million midges, from 21 species of Culicoides were identified. The maximum number of Culicoides caught in one night was in excess of 21,000 midges in the R.O.I. [72]. A similar surveillance network in N.I. operating at 14 trapping sites caught a maximum of around 36,000
Culicoides per night in N.I. [Dr. Stephen Jess, unpublished observations]. Of the Culicoides identified, approximately $73 \%$ were considered to be potential AHSV vectors (Obsoletus group, 50.6\%; Pulicaris group 22\%) [72]. Initial results indicate that the vector period appears to operate between the beginning of April until mid-November/early December, although midge abundance correlates with weather conditions, most notably wind and temperature [72]. Therefore, it is evident that if AHSV were to be introduced into Ireland there are sufficient vectors present to enable the spread of the virus.

\section{Conclusions}

It is evident from previous outbreaks of AHSV worldwide that this disease can have serious consequences for animal health and mortality. As such, it is likely that any introduction to Ireland would be catastrophic, considering the high population density of vulnerable animals, and the importance of the equine industry to the rural economy. Despite the current risk of importation of AHSV being considered at worst 'very low', a stockpile of live, attenuated vaccines, which are currently used in sub-Saharan Africa, has been created for the potential use in the European Union should an outbreak occur [9]. These vaccines are not currently considered to be an option for Ireland, as there may be a risk of the vaccine reverting to the wild-type virus, causing virulence and spreading the disease [9]. However, DEFRA has recently initiated a three year project with the aim of developing a safer and more effective vaccine against AHSV [73]. Consequently, there is an important need for continued vigilance in Ireland with regard to arthropod-borne diseases such as AHSV and BTV in order to protect livestock, the agricultural industry, and the rural economy as a whole.

\section{Abbreviations}

AHS: African horse sickness; AHSV: African horse sickness virus; AHSV1: African horse sickness virus serotype 1; AHSV-4: African horse sickness virus serotype 4; AHSV-9: African horse sickness virus serotype 9; BT: Bluetongue; BTV: Bluetongue virus; BTV-8: Bluetongue virus serotype 8; DARD: Department of Agriculture and Rural Development Northern Ireland; DEFRA: Department for Environment, Food and Rural Affairs; EFSA: European Food Safety Authority; N.I.: Northern Ireland; OIE: The World Organisation for Animal Health; RNA: Ribonucleic acid; R.O.I.: Republic of Ireland.

\section{Competing interest}

None of the authors of this manuscript has any financial or personal relationship with other people or organisations that could inappropriately influence or bias the content of this paper.

\section{Acknowledgements}

We would like to show our appreciation to the Department of Agriculture and Rural Development Northern Ireland for funding this research.

\section{Authors' contributions}

GMT, SJ, and AKM drafted the manuscript and compiled the literature. All authors made substantial inputs to the review, critically discussed, and approved the final manuscript. 
Received: 25 January 2012 Accepted: 3 May 2012

Published: 3 May 2012

\section{References}

1. Lord CC, Venter GJ, Mellor PS, Paweska JT, Woolhouse MEJ: Transmission patterns of African horse sickness and equine encephalosis viruses in South African donkeys. Epidemiol Infect 2002, 128:265-275.

2. Mellor PS, Hamblin C: African horse sickness. Vet Res 2004, 35:445-466.

3. Boinas F, Calistria P, Domingo M, Martínez-Avilés M, Martínez-López B, Rodríguez-Sánchez B, Sánchez-Vizcaíno JM: Scientific report submitted to EFSA on African Horse Sickness., [http://www.efsa.europa.eu/en/ supporting/doc/4e.pdf].

4. Wilson A, Mellor PS, Szmaragd C, Mertens PPC: Adaptive strategies of African horse sickness virus to facilitate vector transmission. Vet Res 2009, 40(2):16.

5. Awad Fl, Amin MM, Salama SA, Aly MM: The incidence of African horse sickness antibodies in animals of various species in Egypt. Bull Anim Hlth Prod Afr 1981, 29:285-287.

6. Van Rensburg IBJ, Declerk J, Groenewald HB, Botha WS: An outbreak of African horsesickness in dogs. J S Afr Vet Assoc 1981, 52:323-325.

7. Alexander KA, Kat PW, House J, House C, Obrien SJ, Laurenson MK, McNutt JW, Osburn Bl: African horse sickness and African carnivores. Vet Microbiol 1995, 47:133-140.

8. World Organisation for Animal Health: OIE Listed diseases., [http://www.oie. int/en/animal-health-in-the-world/oie-listed-diseases-2011].

9. Allison K, Taylor N, Upton M, Wilsmore T: African Horse Sickness. Impact on the UK Horse Industry. The potential effects on businesses, horses and horse owners., [http://www.veeru.reading.ac.uk/documents/AHS\%20-\%20HT \%20-\%20Report\%20final\%20301109.pdf].

10. Moule L: Histoire de la Medecine Veterinaire. Paris: Maulde; 1896.

11. Henning MM: African horse sickness, perdesiekte, Pestis equorum. In Animal Diseases in South African. 3rd edition. Edited by. South Africa: Central News Agency; 1956:785-808.

12. Baylis M, Mellor PS, Meiswinkel R: Horse sickness and ENSO in South Africa. Nature 1999, 397:574-574.

13. Coetzer JAW, Erasmus BJ: African horse sickness. In Infectious diseases of livestock with special reference to southern Africa. Volume 1. Edited by Coetzer JAW, Thompson GR, Tustin RC. Cape Town: Oxford University Press; 1994:460-475

14. Barnard BJ: Epidemiology of African horse sickness and the role of the zebra in South Africa. Arch Virol Suppl 1998, 14:13-19.

15. World Organisation for Animal Health: Afican horse sickness, South Africa [http://web.oie.int/wahis/public.php? page $=$ single_report $\& p o p=1 \&$ reportid $=10651$ ]

16. Howell PG: The 1960 epizootic in the Middle East and SW Asia. J S Afr Vet Med Assoc 1960, 31:329-334.

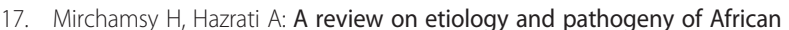
horse sickness. Arch Razi Inst 1973, 25:23-46.

18. Hamblin C, Salt JS, Mellor PS, Graham SD, Smith PR, Wohlsein P: Donkeys as reservoirs of African horse sickness virus. Arch Virol Supp/ 1998, 14:37-47.

19. Lubroth J: African horse sickness and the epizootic in Spain 1987. Equine Pract 1988, 10:26-33.

20. Mellor PS: African horse sickness - transmission and epidemiology. Vet Res 1993, 24:199-212.

21. Anonymous: African horse sickness. In Manual of Recommended Diagnostic Techniques and Requirements for Biological Products for lists A \& B Diseases. Volume 3. Edited by. OlE; 1991.

22. Rodriguez M, Hooghuis H, Castano M: African horse sickness in Spain. Vet Microbiol 1992, 33:129-142

23. Portas M, Boinas FS, Sousa JOE, Rawlings P: African horse sickness in Portugal: a successful eradication programme. Epidemiol Infect 1999, 123:337-346.

24. Howell PG: The isolation and identification of further antigenic types of African horse sickness virus. Onderstepoort J Vet Res 1962, 29:139-149.

25. Spence RP, Moore NF, Nuttall PA: The biochemistry of Orbiviruses. Arch Virol 1984, 82:1-18

26. Mertens PPC, Maan S, Samuel A, Attoui H: Orbivirus, Reoviridae. In Virus Taxonomy. Edited by Fauquet CM, Mayo MA, Maniloff J, Desselberger U, Ball LA. London: Academic Press; 2005:466-483.

27. Grubman MJ, Lewis SA: Identification and characterization of the structural and nonstructural proteins of African horsesickness virus and determination of the genome coding assignments. Virology 1992, 186:444-451.
28. Mertens PPC, Pedley S, Cowley J, Burroughs JN, Corteyn AH, Jeggo MH, Jennings DM, Gorman BM: Analysis of the roles of Bluetongue virus outer capsid protein-VP2 and protein-VP5 in determination of virus serotype. Virology 1989, 170:561-565.

29. Martinez-torrecuadrada $\mathrm{J}$, Casal Jl: Identification of a linear neutralization domain in the protein VP2 of African horse sickness virus. Virology 1995, 210:391-399.

30. Martinez-Torrecuadrada JL, Langeveld JPM, Venteo A, Sanz A, Dalsgaard K, Hamillon WDO, Meloen RH, Casal Jl: Antigenic profile of African horse sickness virus serotype 4 VP5 and identification of a neutralizing epitope shared with bluetongue virus and epizootic hemorrhagic disease virus. Virology 1999, 257:449-459.

31. Mertens PPC, Mellor PS: Bluetongue. State Vet J 2003, 13:18-25.

32. Mellor PS: Epizootiology and vectors of African horse sickness virus. Comp Immunol Microbiol Infect Dis 1994, 17:287-296.

33. Barnard BJH, Bengis R, Keet D, Dekker EH: Epidemiology of African horsesickness - Duration of viremia in zebra (Equus-burchelli). Onderstepoort J Vet Res 1994, 61:391-393.

34. Erasmus BJ: The pathogenesis of African horse sickness. In Proceedings of the 3rd International Conference of Equine Infectious Diseases. Edited by Bryans JT, Gerber H. Paris, France:; 1973:1-11.

35. Mellor PS: Replication of arboviruses in insect vectors. J Comp Pathol 2000, 123:231-247.

36. Toit RM: The transmission of bluetongue and horsesickness by Culicoides. Onderstepoort J Vet Anim Industry 1944, 19:7-16.

37. Borkent A, Wirth WW: World species of biting midges (Diptera: Ceratopogonidae). Bull Am Mus Nat Hist 1997, 233:5-257.

38. European Food Safety Authority: Scientific Opinion of the Scientific Pane on Animal Health and Welfare on the EFSA Selfmandate on bluetongue and occurrence. EFSA J 2007, 408:1-20.

39. Bouayoune H, Touti J, el Hasnaoui H, Baylis M, Mellor PS: The Culicoides vectors of African horse sickness virus in Morocco: distribution and epidemiological implications. Arch Virol Supp/ 1998, 14:113-125.

40. Meiswinkel R: The 1996 outbreak of African horse sickness in South Africa-the entomological perspective. Arch Virol Supp/ 1998, 14:69-83.

41. Mellor PS, Boorman J, Jennings M: Multiplication of African horse-sickness virus in 2 species of Culicoides (Diptera, Ceratopogonidae). Arch Virol $1975,47: 351-356$.

42. Mellor PS, Hamblin C, Graham SD: African horse sickness in Saudi-Arabia. Vet Rec 1990, 127:41-42.

43. Mellor PS, Boned J, Hamblin C, Graham S: Isolations of African horse sickness virus from vector insects made during the 1988 epizootic in Spain. Epidemiol Infect 1990, 105:447-454.

44. Venter GJ, Graham SD, Hamblin C: African horse sickness epidemiology: vector competence of South African Culicoides species for virus serotypes 3, 5 and 8. Med Vet Entomol 2000, 14:245-250.

45. Meiswinkel R, Paweska JT: Evidence for a new field Culicoides vector of African horse sickness in South Africa. Prev Vet Med 2003, 60:243-253.

46. Ozawa $Y$, Nakata G: Experimental transmission of African horse sickness by means of mosquitoes. Am J Vet Res 1965, 26:744-748.

47. Ozawa Y, Nakata G, Shad-del F, Navai S: Transmission of African horsesickness by a species of mosquito, Aedes aegypti linnaeus. Am J Vet Res 1966, 27:695-697.

48. Ozawa Y, Shad-Del F, Nakata G, Navai S: Transmission of African horse sickness by means of mosquito bites and replication of the virus in Aedes-aegypti. Arch Inst Razi 1970, 22:113-122.

49. Braverman $Y$, Boorman $\mathrm{J}$ : Rates of infection in, and transmission of, African horse-sickness virus by Aedes-aegypti mosquitoes. Acta Virol 1978, 22:329-332.

50. Salama SA, El-Husseine MM, Abdulla SK: Isolation and identification of African horse sickness virus in the camel tick. In 4th Annual Report, US AHS project. Edited by. Cairo; 1980:91-98.

51. Tesh RB, Chanioti BN, Johnson KM: Vesicular stomatitis-virus (Indiana serotype) - Transovarial transmission by Phlebotomine Sandflies. Science 1972, 175:1477-1479.

52. Watts DM, Pantuwatana S, Defoliart GR, Yuill TM, Thompson WH: Transovarial transmission of lacrosse virus (California encephalitis group) in mosquito, Aedes triseriatus. Science 1973, 182:1140-1141.

53. White DM, Wilson WC, Blair CD, Beaty BJ: Studies on overwintering of bluetongue viruses in insects. J Gen Virol 2005, 86:453-462.

54. Sellers RF, Mellor PS: Temperature and the persistence of viruses in Culicoides spp. during adverse conditions. Rev Sci Tech OIE 1993, 12:733-755. 
55. Mellor PS, Wellby MP: Effect of temperature on African horse sickness virus infection of and transmission by vector species of Culicoides (Diptera: Ceratopogonidae). In Proceedings of the 8th International Conference on Equine Infectious Diseases. Edited by Werney U, Wade JF, Mumford JA, Kaaden OR.: R \& W Publications; 1999:246-251.

56. Boorman J: A review of Culicoides subgenus Avaritia species (Insecta Diptera, Ceratopogonidae), vectors of viruses of sheep, cattle, and horses, with particular reference to Culicoides imicola in Europe and the Mediterranean region. In Report prepared for The Overseas Development Administration. Edited by. 1991.

57. Capela R, Purse BV, Pena I, Wittman EJ, Margarita Y, Capela M, Romao L, Mellor PS, Baylis M: Spatial distribution of Culicoides species in Portugal in relation to the transmission of African horse sickness and bluetongue viruses. Med Vet Entomol 2003, 17:165-177.

58. Menzies FD, McCullough SJ, McKeown IM, Forster JL, Jess S, Batten C, Murchie AK, Gloster J, Fallows JG, Pelgrim W, Mellor PS, Oura CAL: Evidence for transplacental and contact transmission of bluetongue virus in cattle. Vet Rec 2008, 163:203-209.

59. Wilson A, Darpel K, Mellor PS: Where does bluetongue virus sleep in the winter? Plos Biol 2008, 6:1612-1617.

60. Henessy K, Quinn K: The Future of the Irish Sport Horse Industry. Analysis and Recommendations., [http://www.irishsporthorse.com/_fileupload/ publications/strategic_with\%20cover.pdf].

61. Dukes A: Analysis of the economic impact of the Irish Thoroughbred Horse Industry., [http://www.itba.info/PDFdukes/dukes_report.pdf].

62. Department of Agriculture and Rural Development: Research on the Equine sector in Northern Ireland., [http://www.dardni.gov.uk/equinereport.doc].

63. Aznar I, McAteer B, Gaynor S: Risk assessment of the introduction of African Horse Sickness (AHS) into the Republic of Ireland (ROI)., [http:// www.agriculture.gov.ie/media/migration/animalhealthwelfare/ diseasecontrols/ RiskassessmentoftheintroductionofAfricanHorseSickness230311.pdf].

64. Sellers RF, Pedgley DE, Tucker MR: Possible spread of African horse sickness on the wind. J Hyg 1977, 79:279-298.

65. MacLachlan NJ, Guthrie AJ: Re-emergence of bluetongue, African horse sickness, and other Orbivirus diseases. Vet Res 2010, 41(6):35.

66. Department for Environment Food and Rural Affairs: Update No.6 on Schmallenberg Virus in Northern Europe., [http://www.defra.gov.uk/ animal-diseases/files/poa-schmallenberg-update-120311.pdf].

67. Gloster J, Burgin L, Witham C, Athanassiadou M, Mellor PS: Bluetongue in the United Kingdom and northern Europe in 2007 and key issues for 2008. Vet Rec 2008, 162:298-302.

68. Department for Environment Food and Rural Affairs: African Horse Sickness in horses in South Africa. Preliminary Outbreak Assessment., [http:/ archive.defra.gov.uk/foodfarm/farmanimal/diseases/monitoring/documents/ poa-southafrica1 10310.pdf]

69. Follett B, Allen P, Bateson P, Black D, Brown F, Eddy R, Leather S, Levin S, Linklater K, Longfield J, McConnell I, McLean A, McMichael A, Mumford J, Weiss R, Westergaard J: Infectious diseases in livestock. London: The Royal Society; 2002.

70. Wilson AJ, Mellor PS: Bluetongue in Europe: past, present and future. Phil Trans R Soc B 2009, 364:2669-2681.

71. Mintiens K, Meroc E, Mellor PS, Staubach C, Gerbier G, Elbers ARW, Hendrickx G, De Clercq K: Possible routes of introduction of bluetongue virus serotype 8 into the epicentre of the 2006 epidemic in NorthWestern Europe. Prev Vet Med 2008, 87:131-144.

72. McCarthy TK, Bateman A, Nowak D, Higgins T, Geraghty F, Sheehy E, Kirrane A, Moran P, Lawless A: BTV Vector Surveillance 2007-2008, 1st Annual Technical Report., [http://www.agriculture.gov.ie/media/migration/ animalhealthwelfare/diseasecontrols/bluetonguedisease/ BTV Vector Surveillance_2007.pdf].

73. Anonymous: Improving vaccines for African horse sickness. Vet Rec 2010, 167:38-38.

doi:10.1186/2046-0481-65-9

Cite this article as: Thompson et al:: A review of African horse sickness and its implications for Ireland. Irish Veterinary Journal 2012 65:9.

\section{Submit your next manuscript to BioMed Central and take full advantage of:}

- Convenient online submission

- Thorough peer review

- No space constraints or color figure charges

- Immediate publication on acceptance

- Inclusion in PubMed, CAS, Scopus and Google Scholar

- Research which is freely available for redistribution 